\title{
Grafične pripovedi in pripovednost
}

Leonora Flis

Univerza v Ljubljani, Fakulteta za socialno delo, Topniška 31, 1000 Ljubljana, Slovenija

Univerza v Novi Gorici, Vipavska 13, 5000 Nova Gorica, Slovenija

https://orcid.org/0000-0003-4190-2548

leonora.flis@fsd.uni-lj.si

Grafične pripovedi se nahajajo na stičišču prikazovanja in pripovedovanja zgodbe, v vsakem primeru pa zgodbo pripovedujejo, torej predstavljajo narativen žanr. Grafično pripovedovanje omogoča zastavljanje temeljnih vprašanj, ki zadevajo na primer temporalni aspekt narativnosti (razumljene kot skupek formalnih in kontekstualnih lastnosti, ki določajo pripoved) in področje fokalizacije. Grafične pripovedi s pripovednim časom upravljajo nekoliko drugače od (zgolj) literarnih besedil, saj občutek časa ustvarjajo z razmerjem med vizualnim in verbalnim. Nadalje poleg (po navadi uokvirjenih) ilustracij vsebujejo tudi tako imenovani "gutter", "jarek" ali "luknjo ", torej vmesne prazne prostore. Teoretik in stripar Scott McCloud pravi, da je prav ta prostor $v$ grafičnem romanu najkreativnejši; je praznina, ki najbolj buri bralčevo domišljijo, obenem pa tudi prostor, kjer se zgodi iluzija premika prostora in časa. Na primerih nekaj stripov (izpostavljeni avtorji so Art Spiegelman, Joe Sacco in Marjane Satrapi) članek prikaže specifike grafičnega pripovedovanja, ki s sekvenčnostjo podob, montažo kadrov, kompozicijo posameznih strani in drugimi strukturnimi karakteristikami omogočajo grajenje in vzdrževanje zgodbe. Ko govorimo o grafičnih pripovedih, je torej ustrezno govoriti o čezžanrski in čezmedijski naratologiji, zato razprava izpostavi tudi vlogo postklasične naratologije pri interpretaciji in razumevanju tovrstnih zgodb.

Ključne besede: postklasična naratologija / hibridni žanri / roman v stripu / grafični roman / grafična pripoved / narativnost / Spiegelman, Art / Satrapi, Marjane / Sacco, Joe 


\section{Grafična pripovednost kot multimodalnost}

Grafični romani ali širše grafične pripovedi ${ }^{1}$ (GP) predstavljajo hibridni žanr, ki v sebi združuje literarno in vizualno pripovedno linijo. Kompleksnejše GP so se šele v poznih 80. letih in zgodnjih 90. letih prejšnjega stoletja osvobodile predsodka, da so stripovske zgodbe namenjene zgolj mlajšim, da so preproste in enoplastne; postale so komercialno uspešnejše in tudi prepoznane kot legitimen literarno-umetniški pojav. ${ }^{2}$ GP se umeščajo v kategorijo multimodalnih pripovedi, ki za upodabljanje pripovednih svetov uporabljajo dve semiotični liniji, verbalno in vizualno. $\mathrm{Za}$ naratologe danes predstavljajo pomembno področje raziskovanja (čeprav raziskav na področju naratologije stripa še ni prav veliko); za njihovo interpretacijo pa je potrebna holistična analitična metoda (podobno kot za filmsko naracijo ali animacijo). Stripar in teoretik Will Eisner v svojem teoretičnem delu Comics and Sequential Art zapiše, da film, animacija in stripi (tu termin "strip" uporablja v najširšem pomenu besede, saj z njim zaobjame vse od kratkih stripov v časopisju do grafičnih romanov) za pripovedovanje uporabljajo (grafične) podobe ter besedilo ali dialog, a ne glede na medij

${ }^{1}$ Raje kot izraz grafični roman (termin se je uveljavil zlasti po izdaji dela Willa Eisnerja leta 1978 z naslovom A Contract with God: A Graphic Novel) v članku uporabljam izraz grafična pripoved, saj vse pripovedi, ki se jim velikokrat, vsaj v anglo-ameriškem prostoru, pripisuje oznaka "grafični roman« (graphic novel), ne ustrezajo kriterijem za roman kot literarno zvrst s specifičnimi zakonitostmi in zahtevami do pisca in bralca. V svoji odločitvi za oznako grafična pripoved tako pritrjujem ameriški literarni znanstvenici Hilary L. Chute, ki je v svojih delih, vključno s knjigo Graphic Women: Life Narrative and Contemporary Comics, izrazila preferenco do izraza "grafična zgodba/ pripoved « (graphic narrative; Flis 144-145). Grafična pripoved je torej krovni termin, označuje pa sekvenčno urejene podobe, ki jih pogosto dopolnujejo ali podkrepljujejo napisi, oblački ali drugi verbalni elementi. V članku so izpostavljene kompleksnejše zgodbe, ki presegajo nivo kratke sekvenčnosti podob in teksta; analizirane zgodbe so po navadi namenjene odraslemu bralcu, prevladujoči žanri pa so biografija, avtobiografija, literarni žurnalizem v podobi grafične zgodbe in zgodovinska pripoved. Nekateri teoretiki (npr. Scott McCloud) pa uporabljajo kot krovni termin kar izraz strip. Pri nas se uveljavlja tudi izraz risoroman (kot sopomenka za grafični roman), ki spet vključuje predpostavko, da izbrano delo ustreza zapovedim romana. Roman je zelo odprta in prilagodljiva literarna vrsta, ki se lahko širi na območje biografije, avtobiografije, romana v verzih, scenariziranega romana in tako dalje, vseeno pa je navzoča zahteva, da gre za daljše zapise. Termina risoroman (ki je sprejemljiv in uporaben za ožji segment grafičnih pripovedi) ne zavračam, vseeno pa se odločam za grafično pripoved, saj želim vendarle govoriti o žanru kot takem (ki lahko vključuje tudi kratka zaporedja podob in besed) in ne o specifični literarni vrsti znotraj tega žanra.

${ }^{2}$ Glej tudi Baetens, Frey in Tabachnick 1-18. 
je zgradba zgodbe pravzaprav bolj ali manj enaka; to pomeni, da se pristopi $\mathrm{k}$ analizi omenjenih vrst pripovedovanja na nekaterih točkah staknejo. Če se oprem na postavke postklasične naratologije, ki mi bo pri analizi GP pomagala, je treba zgodbo razumeti $v$ širokem pomenu besede in se zavedati, da smo v domeni pretočnosti terminov. Ali kot v delu Teorija pripovedi zapiše Alojzija Zupan Sosič:

Postklasična teorija pripovedi se od klasične razlikuje v poudarjanju konteksta, besedila in bralca oziroma kritika. [...] V nasprotju s klasično (predvsem strukturalistično) naratologijo, ki je bila usmerjena $\mathrm{k}$ nezgodovinskim univerzalijam, je postklasična naratologija bolj diahrona, saj interdisiplinarno raziskuje pripovedno kot večplastni pojav, usmerjen tudi v okoliščine in posledice različnih branj. ${ }^{3}(30)$

Pripoved v kontekstu GP razumem tudi v smislu pripovedi, kot jo pojmuje Roland Barthes. Barthes namreč meni, da so zgodbe univerzalne v smislu, da nam jih lahko posreduje katerikoli medij (237-272). Kot zapiše Alenka Koron v delu Sodobne teorije pripovedi:

Barthesova opredelitev pripovedi, na katero se mnogi sklicujejo, je implicitno speta z vsebino, vendar je hkrati jasno razvezana od besedilne podlage in zajeta kot semiotični pojav, ki se lahko manifestira besedno ali v nebesedni obliki, znotraj ali onkraj literature, torej tudi v drugih, nebesednih medijih, v likovni umetnosti, na vitrajih, v filmu, stripu, v različnih dejstvih [...]. (26)

Pri analizi GP, kot jo zasnujem v tem zapisu, se torej odmikam od tradicionalne literarne teorije in klasične naratologije. Adrijana Marčetić v članku »Postklasična naratologija» pravilno ugotavlja, da sodobna naratologija na pripovedovanje gleda skozi transmedialno perspektivo, saj pripovedovanje vidi kot pojav, ki je skupen različnim medijem: literature, filmu, stripu, plesu, gledališču in vsakodnevni komunikaciji. Zapišse še:

${ }^{3}$ Zupan Sosič v svojem članku »Postklasična teorija pripovedi« razloži tudi, da je konec tradicionalne literarne teorije in teorije književnosti na splošno zaobsežen že v samem konceptu postmoderne (opre se na teorijo Fredrica Jamesona). Današnja teorija pripovedi je tako ali tako pojmovanje za naratologijo v širšem smislu in se ne nanaša zgolj na metodo (post)strukturalizma (če jo zožimo na metodo, ki se je razvila iz strukturalne poetike in semiotike) (Zupan Sosič, »Postklasična« 497). "Širše poimenovanje pa si zasluži samo tista naratologija, ki je odstopila svoje tradicionalno poslanstvo polivalentni teoriji pripovedovanja in tako premestila svoj raziskovalni poudarek s proze na pripoved.«(Prav tam) 
Če govorimo o metodi, je tudi metoda sodobne naratologije trans- ali pa interdisciplinarna. Sodobni naratologi se poslužujejo različnih metod - zgodovinskih, lingvističnih, psiholoških, filozofskih, pravnih, socioloških, antropoloških in drugih. Interdisciplinarnost je pravzaprav ena največjih vrlin sodobnih teorij pripovedovanja in predstavlja velik napredek $\mathrm{v}$ primerjavi z dosežki klasične naratologije. ${ }^{4}(77)$

Med najpomembnejšimi področji postklasične teorije pripovedi so kulturna, kognitivna, retorična, feministična in spolnoidentitetna naratologija. Pri razlagi GP se zdi, kot bom pokazala v nadaljevanju, najbolj izstopajoča in najuporabnejša kognitivna naratologija. ${ }^{5}$ Občasno teoretiki GP omenjajo tudi kulturno naratologijo. Joe Baetens recimo v članku »Stories and Storytelling« pravi, da je razlog za uspeh GP tudi to, da nudijo odgovor na specifičen zgodovinski in kulturološki problem, ki, kot meni, postane še posebej izrazit v 80. letih prejšnjega stoletja: visoka, sofisticirana literatura, ki je preplavljala tržišče, ni več zadovoljila bralstva. Baetens torej razlaga GP kot postmoderni fenomen. ${ }^{6}$ Zato avtorji iščejo alternative. Pojavila se je potreba po »družbeno in osebno uporabni pripovedi in pripovedovanju, «zapiše Baetens (31). To seveda ne pomeni, da so GP v domeni preprostega in enoplastnega, vseeno pa gre za medij, ki je dostopnejši širšemu krogu bralcev. Baetens pravi tudi, da moramo GP zaradi raznolikosti njihovih pojavnih oblik in tudi zaradi nenehnega preoblikovanja in modificiranja medija videti kot prostor, ki nakazuje na spremembe na področju pripovedovanja nasploh. Zato predlaga, da GP tolmačimo tudi s pomočjo principov kulturne naratologije (41). A. Zupan Sosič opaža, da je v zadnjem desetletju kognitivna naratologija v postklasični naratologiji zasenčila kulturno naratologijo (ki v analizo pripovedi vključuje tudi študij delovanja družbenih, gospodarskih in političnih vplivov ter pomeni preplet sociologije, antropologije, kulturologije, če naštejemo nekaj pristopov). Kognitivna naratologija pa raziskuje »razmerja med percepcijo, jezikom, znanjem, spominom in svetom; zanimajo jo vloge zgodbe v okviru sečišč in nizov različnih pojavov" (Zupan Sosič, Teorija 31). Zupan Sosič pojasni tudi, da je ena izmed nalog kognitivne nara-

${ }^{4}$ Prevod Leonora Flis.

${ }^{5} \mathrm{O}$ delitvi naratologije na klasično in postklasično je pri nas prva pisala Alenka Koron v svoji disertaciji Novejš teorije pripovedi $v$ literarni vedi in njihova raba $v$ slovenski in tujih književnostih. Glej tudi David Herman, "Introduction" 1-30.

${ }^{6} \mathrm{O}$ začetkih postmodernizma seveda obstaja več teorij. $\mathrm{O}$ rahljanju mej med visoko in nizko literaturo ali sofisticirano in popularno umetnostjo vsekakor lahko govorimo najmanj dve desetletji pred začetkom, ki ga omenja Baetens. 
tologije, ki jo lahko pojmujemo tudi kot multidisciplinarni projekt, analiza delujočih ali opuščenih kognitvnih okvirjev v bralnem procesu (prav tam). Bralčeva percepcija pa je gotovo ena od ključnih postaj pri raziskavi GP.

Pri GP kot multimodalnem mediju se tako kažejo naslednja vprašanja: kako bralci v GP iz kombinacije slik in besed sestavljajo pripovedne svetove, kako se v GP med seboj prepletajo semiotični kanali, kako se GP primerjajo z drugimi multimodalnimi mediji ali pripovedmi, na primer s filmskimi, kako podobe (slike, ilustracije), besede in sekvence podob sploh oblikujejo narativni potencial grafičnih pripovedi ter kako razvrstitev okvirjev implicira časovni potek dogajanja. GP so odličen primer sodelovanja med različnimi pripovednimi modalitetami, in prav zato je ta medij tako pomemben za transmedialno naratologijo. Vsaka od teh modalnosti ali modalitet deluje kot sistem izbir, ki imajo za cilj posredovanje pomena. Razumevanje GP tako zahteva sprejetje dinamičnega prepleta modalitet in teoretičnih pristopov.

Kot zapisano, je v GP verbalna modaliteta vedno v interakciji z vizualno modaliteto in s sekvenčno naravo medija, med modalitetami je ves čas prisoten dinamičen proces sovplivanja in medsebojnega dopolnjevanja. ${ }^{7}$ Stripovski kader, torej ena sličica, je najmanjši del stripa. Ko nizamo kader za kadrom, sličico za sličico, sestavljamo zgodbo. GP pa poleg podob in teksta vsebujejo tudi prostor med okvirji. Scott McCloud (Kako razumeti strip) to "belino" imenuje "gutter" (luknja, praznina); $v$ tem razmaku med sličicama se odvija, kot pravi McCloud, večina tiste "čarovnije in skrivnosti, ki tvorita samo srž stripovske umetnosti. [...] [I]n prav tu, v vmesni praznini beline, človeška domišljija zlije dve ločeni sličici v en sam, enoten koncept. « ${ }^{8}$ (66) Bistvo stripa je po mnenju McClouda prav v tovrstnem dopolnjevanju. Med bralcem in avtorjem se sklepa nekakšna tiha in tajna pogodba. Šele bralec je

${ }^{7}$ Will Eisner (Comics and Sequential Art) strip (to je izraz, ki ga najpogosteje uporablja) konsistentno definira kot "sequential art ", torej kot umetnost sekvence ali zaporedja in pretežno iz sekvenčnosti razlaga poglavitne karakteristike tega medija. Glej tudi Karin Kukkonen, „Comics«.

${ }^{8}$ Joyce Goggin in Dan Hassler-Forest, ki sta uredila knjigo The Rise and Reason of Comics, $\mathrm{v}$ "Uvodu“ opišeta ta prazen prostor kot edini bistveni element, ki definira GP kot samostojen žanr in ne podžanr literature ali pa grafične umetnosti v širšem pomenu besede. Pravita, da je bralčevo sodelovanje v praznem prostoru odločilnega pomena za razumevanje GP. Sprašujeta se tudi o tem, koliko svobode pri interpretaciji GP ima bralec in ugotavljata, da je prav gutter prostor največje svobode, saj okvirji že določajo potek in način bralčevega razumevanja in interpretacije. 
tisti, ki poveže kadre v smiselno celoto, torej »zažene« zgodbo. Strip od bralca zahteva nenehno sodelovanje, bralci smo pomožni animatorji. McCloud v delu Kako nastane strip poudari tudi, da mora avtor stripa, da bi dosegel svoj cilj, osvojiti načela jasne komunikacije.

Naučiti se morate, kateri elementi nekega dela lahko publiko prepričajo, da ostane z vami. Strip od nas zahteva, da nenehno izbiramo podobe, tempo, dialog, kompozicijo, geste in cel kup drugih elementov. Vse te izbire pa lahko strnemo v pet osnovnih tipov: izbor trenutka, izbor kadra, izbira slike, izbira besed in izbor poteka. (9-10)

Kognitivna naratologija na primer predpostavlja, da bralec pristopi $\mathrm{k}$ branju z določenimi kognitivnimi vzorci in shemami, ki omogočajo smiselno organizacijo različnih, med seboj povezanih konceptov; ti okvirji in sheme so povezani z bralčevimi preteklimi izkušnjami. S pomočjo teh vzorcev in shem bralec sklepa, domneva in ustvarja hipoteze.

Pascal Lefevre v članku »Narration in Comics« jasno pokaže na tesno povezavo med GP in kognitivno naratologijo ter izpostavi, da so za razumevanje GP pomembni tudi izsledki in koncepti kognitivne psihologije. Če se bralcu zapisano in izrisano ne bo zdelo zanimivo ali ne bo prepoznal podob in simbolov, bo prenehal z branjem in interpretacijo. Omenja dela naratologov, kot so Bordwell, Reid, Fludernik in Herman, saj so med tistimi, ki poudarjajo vlogo bralca in način, kako tekst pritegne bralca $\mathrm{v}$ proces semantične izmenjave in interakcije. Lefèvre se sprašuje, kako GP usmerjajo bralca v določeno branje s pomočjo svoje forme in pa kako lahko bralci tudi brez tekstualnih "namigov« aktivirajo določena znanja in razumevanja besedila in vizualne podobe. Podobe v GP kažejo dejanja, situacije ali predmete in bralec jih po navadi brez težav prepoznava in razume. Bralec prav tako prepozna pomen okvirja in domneva tudi, da se fikcijski svet ne konča na robu okvirja. Bralec GP pristopi k branju z določenimi kognitivnimi okvirji in shemami in z njimi lahko, na podlagi preteklih izkušenj, različne, med seboj povezane, koncepte povezuje v smiselne celote. ${ }^{9} \mathrm{Na}$ tem mestu se zdi smiselno omeniti teorijo Wolfganga Iserja, ki govori o praznih mestih $\mathrm{v}$ besedilu oziroma besedilni strukturi, ki pogojujejo sodelovanje bralca. ${ }^{10}$ Po Iserju pomembne prvine literarnega dela ostajajo neizrečene in se realizirajo šele v bralčevi domišljiji (glej tudi Zupan Sosič, Teorija 263).

${ }^{9}$ Lefèvre se opre tudi na delo Roberta J. Sternberga Cognitive Psychology (1996), knjigo Davida Bordwella Narration in the Fiction Film (1985) ter na Karla Haberlandta in njegovo delo Cognitive Psychology (1994).

${ }^{10}$ Glej Iser, Bralno dejanje. 
Nadalje lahko po analogiji z Gadamerjevim horizontom pričakovanja izpostavim tudi, da bralec pri branju GP uporablja svoje inzventekstovne, "zunanje« sheme; njegova pričakovanja se preverjajo s svojo (ne)izpolnitvijo znotraj pripovednega sveta GP. Obenem je bralec pozoren tudi na norme, ki jih postavlja GP. Te notranje zapovedi so lahko v skladu s konvencijami zunanjega sveta, ki jih bralec prinese $\mathrm{v}$ branje, ali pa odstopajo od njih. Bralec mora sprejeti, da razporeditev okvirjev na posamezni strani ni naključna, ampak določena, in da so podobe v okvirjih med seboj povezane. Tvorijo sekvenco zaporednih situacij. Sledeč izsledkom kognitivne psihologije je ustrezno reči, da je naša interakcija z okoljem in $\mathrm{z}$ drugimi ljudmi pravzaprav zgrajena na principu sekvenčnosti. Če poznamo zaporedje dogodkov v vsakodnevnem življenju, verjetno ne bomo imeli težav pri razumevanju prikaza takšnih sekvenc v GP. Res pa je, da nekateri prikazi zahtevajo od bralca več domišljije kot drugi. Poleg tega za GP ni nujno, da so sekvence zgrajene po principu enake kontinuitete, kot jo najdemo v vsakodnevnem življenju. Pravzaprav to ni mogoče. Stripi in GP so že zaradi zahtev medija eliptične pripovedi. Za razliko od filmov in gledaliških iger lahko GP predstavljajo le fragmente dogodkov (in predmetov). GP tako zgolj s prikazom posameznih ključnih dejanj nakažejo celotno zaporedje dogodkov. Ko pristopimo h GP, moramo tako vedno vzeti v zakup, da imamo opravka z medijem eliptičnega in fragmentarnega pripovedovanja. V naslednjih odstavkih natančneje pokažem, kakšna je zgradba GP in $v$ kakšno razmerje do pripovednega ob branju vstopa bralec.

\section{Podrobnejša anatomija grafične pripovedi in njene pripovednosti}

Ko govorim o branju GP, ga razumem v širšem pomenu besede - ne le kot branje besed, temveč kot razbiranje simbolov. Podobno tudi Eisner v Graphic Storytelling govori o branju stripov kot o zaznavni aktivnosti. Strip komunicira v jeziku, ki se nanaša na vizualne izkušnje, in skozi te izkušnje se povežeta ustvarjalec in bralec. Podobe in znake v stripu moramo razumeti, šele tako kadri oživijo in lahko govorimo o oblikovanju zgodbe in posredovanju idej. Kot hibridni medij vsebujejo GP dosti prvin, ki si jih delijo z drugimi mediji (film in animacija), vendar jih uporabljajo na sebi lasten in izviren način. Tu mislim na razdelitev zgodbe v posamezne okvirje (v katere avtor »zamrzne« določen segment realnosti), interakcijo med okvirji in njihovo razporeditev na strani, na slog ilustracij, na mizansceno znotraj okvirjev ter način, kako so pove- 
zani verbalni (recimo $\mathrm{v}$ govornih in miselnih balonih) in vizualni elementi. V zahodnem svetu obstaja konvencija branja od leve proti desni in od zgoraj navzdol, vendar lahko z določenimi elementi risbe vrstni red branja tudi spremenimo. Za razliko od filma in animacije, kjer gledalec spremlja kader za kadrom (režiser/avtor ima popoln nadzor nad »branjem " prikazanega), pri stripu bralec vidi naenkrat celotno stran in lahko kadre preskoči oziroma jih pogleda v poljubnem zaporedju. A če želi prebrati zgodbo, kot si jo je zamislil avtor, mora slediti nepisanim pravilom branja od leve proti desni in od zgoraj navzdol. Branje v drugačni smeri za bralca ni čisto samoumevno, zato moramo bralcu pomagati. Če je GP dobro oblikovana in spisana, skoraj ne opazimo, kdaj sprejemamo informacije s slike in kdaj iz besedila - oboje je neločljivo povezano in prepleteno. Kot razloži Špela Štandeker:

\begin{abstract}
Besede, slike in druge ikone tvorijo besednjak jezika, ki mu pravimo strip. Podobno kot literatura tudi strip uporablja dramsko oblikovanje teksta, pripovedno večplastnost, psihologizacijo likov in žanrska pravila. Obenem pa so za stripovski medij pomembni tudi neliterarni postopki, kot so likovni elementi, montaža, izražanje gibanje, iluzija minevanja časa in specifičen avtorski risarski stil, ki gradi stripovsko strukturo. Prav kombinacija teksta in podob tako ustvari jezik, ki besednemu/likovnemu vidiku doda nove razsežnosti in tako ustvari povsem svoj, stripovski jezik. (6)
\end{abstract}

Lahko pritrdim tudi Eisnerjevemu opažanju (v Comics and Sequential $A r t)$, da razumevanje podob v stripu terja bralčevo in piščevo/striparjevo harmonijo izkušnje. Stripar si mora prizadevati razumeti bralčeve življenjske izkušnje in jih upoštevati. Od tega je odvisno, kako uspešno bo bralec prepoznaval podobe in zaznaval njihove miselne in emotivne razsežnosti (7-8). „Uspeh stripa resnično izvira iz umetnikove sposobnosti, da pravilno oceni sposobnost bralčevega razbiranja podob in simbolov, « še zapiše Eisner (39).

Časovni aspekt je v GP zelo pomemben. V GP čas dojemamo prostorsko; v svetu stripa sta namreč čas in prostor eno. Vsaka sličica prikazije določen trenutek ali neko časovno obdobje, naslednja sličica pa prikazuje že novo obdobje in skozi čas se pomikamo tako, da se pomikamo po strani, po prostoru. $\mathrm{V}$ mediju, kjer se prostor in čas tako popolnoma zlivata, razlika med njima pogosto izgine (Hančič 37). Iz zaporedja (dogodkov) izvira naša ideja o času. Na podlagi izkušenj pa sklepamo, kaj se zgodi prej in kaj kasneje ter koliko časa je medtem minilo. Okvirji zreducirajo kronološko zaporedje zgodbe na izbrane fragmentirane enote. Vsak okvir lahko prikazuje le en trenutek ali pa daljše časovno obdobje. Okvirji lahko vsebujejo tudi različne časovne 
segmente. Če je preplet časovnih segmentov zelo zapleten, se od bralca zahteva dodatna pozornost. Res pa je, da lahko bralec poljubno dolgo časa posveti enemu okvirju in ga do potankosti preuči, pregleda celotno stran, lahko se vrne $\mathrm{k}$ določenemu okvirju ali sekvenci in jo vnovič preveri. Poleg tega večina sodobnih GP okvirje še vedno po navadi razvršča v kronološko, linearno zaporedje. Če pa imamo v pripovedi skoke $\mathrm{v}$ preteklost ali $\mathrm{v}$ prihodnost, je to jasno nakazano $\mathrm{z}$ verbalnimi in vizualnimi sredstvi. Ti pogledi naprej in nazaj pa vnovič vsebujejo kronološko sekvenco, ki bralcu pomaga pri orientaciji. Če film gledalca izpostavi neprestanemu gibanju naprej, se v stripu lahko vračamo nazaj ali pa listamo naprej. Lahko rečemo, da so GP v primerjavi s filmom bolj prostorski medij. "Vsak zaporeden filmski posnetek se projicira na isto mesto - na platno, medtem ko mora biti vsak stripovski kader postavljen na drugo mesto od ostalih. Za strip je prostor to, kar je čas za film, « zapiše McCloud v delu Kako razumeti strip (7).

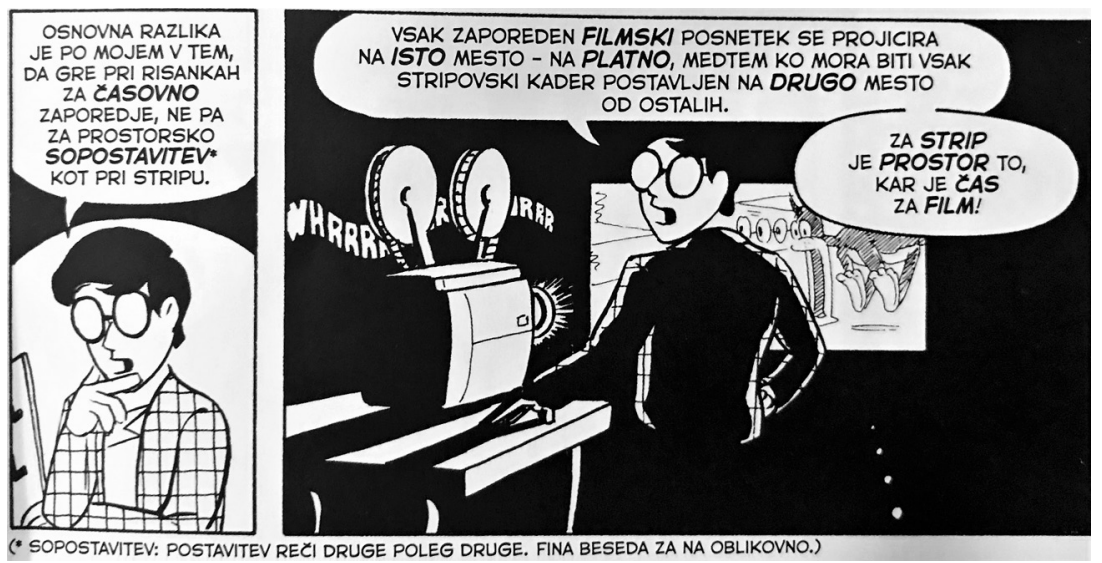

Slika 1: McCloud, Kako razumeti strip 7

V GP sta torej čas in prostor tesno povezana, in iz te postavke sledi ugotovitev, da si v primeru GP zastavljamo vprašanja o dinamiki pripovednega časa in časovni perspektivi pripovednosti nekoliko drugače kot pri literarnih besedilih. Kai Mikkonen (»Remediation«) pojasni, da zato, ker se za ponazoritev časa pač

uporabljajo tako vizualna kot verbalna sredstva, $[\ldots]$ poleg tega pa se GP pri ustvarjanju časovne dimenzije ne zanašajo le prostore/podobe, ki jih vidimo na sličicah, ampak tudi na obrobo, na prazen vmesni prostor [gutter] in na vizualno podobo celotne strani. (74) 
Nadalje se Mikkonen sprašuje, kako bralec serijo podob spreminja v zgodbo, kako kognitivno mapira časovno zaporedje dogodkov. Ugotavlja, da imajo podobe (sličice), tudi če niso del sekvence, ${ }^{11}$ načine, kako izražati temporalnost in kavzalnost (na primer z govorico telesa ali z gestami likov na sličici). Vseeno pa je posamezna slika, kljub temu, da deluje tudi sama po sebi, tako verbalno kot vizualno po navadi povezana še $s$ slikami in okvirji, ki jo obkrožajo, in tako se oblikuje časovni kontinuum. Nekateri okvirji lahko s seboj nosijo več akcije in dogajanje naprej poganjajo z večjo silo kot drugi. Res pa je, da v GP slike $v$ okvirjih predstavljajo izbrane trenutke dane situacije, ki je v bralec $\mathrm{v}$ celoti ne vidi. Zato, kot pravi Mikkonen, je v kontekstu pripovednosti v GP treba misliti tudi na to, da bralec-gledalec ugleda možnost alternativnih posledic dejanj, ki jih prikazujejo okvirji. Prazen prostor je manifestacija simultane prekinitve časa in prostora. Bralec-gledalec si mora $\mathrm{v}$ tem prostoru zamisliti pomen prehoda od ene podobe $\mathrm{k}$ drugi, od enega dejanja $\mathrm{k}$ drugemu. Film dela podobno z montažo; gre za sekvenco posnetkov, ki pokažejo izbrane segmente danega dogodka. Seveda pa pri GP nimamo opravka s časom na platnu, ki bi bil ves čas $\mathrm{v}$ teku, pri GP lahko govorimo o dobesedni liniji podob, ki se materializirajo $\mathrm{v}$ prostoru, in ne o zaporedju podob v času (kot pri filmu). Mikkonen izpostavi še eno pomembno značilnost GP: poleg linearne sekvence podob imajo posamezni okvirji moč interakcije skozi celoten pripovedni kontinuum. GP lahko na isti strani knjige med seboj vizualno povezujejo tudi različne (ne nujno zaporedne) podobe v okvirjih ali pa se povezave vzpostavljajo celo med bolj oddaljenimi deli zgodbe. Poleg tega lahko GP v en sam okvir naenkrat ujamejo različne časovne prostore, pretekli, sedanji in prihodnji; ne da bi kršili pravila verjetnosti, se časovne dimenzije lahko nalagajo ena na drugo ali ena ob drugo. Občutek za čas je tako odvisen od podob v posameznem okvirju, od povezav med okvirji oziroma od bralčevega-gledalčevega aktivnega kognitivnega mapiranja teh povezav (Mikkonen $78-80) .{ }^{12}$ Vpliv na naše dojemanje časa (in ritma pripovedi) ima lahko tudi oblika sličice; daljša sličica (okvir) daje lahko občutek daljšega trajanja. Sličica brez besed, ki v svoji vsebini z ničemer ne izdaja svojega trajanja, pa lahko daje vtis brezčasnosti. Tudi količina detajlov lahko podaljša občutek trajanja, saj oko potrebuje več časa, da se sprehodi po celi sličici.

Res je, da tudi filmska naracija in animacija ne sledita nujno linearnemu poteku dogajanja (uporabljajo se pogledi nazaj ali naprej), vendar

${ }^{11}$ Te imenuje monofazne podobe; pravzaprav je vsaka podoba v GP uokvirjena in deluje kot samostojna entiteta.

${ }^{12}$ Glej tudi Eisner, Comics and Sequential Art 23-30. 
si GP lažje privoščijo tovrstne skoke (lahko tudi v enem samem okvirju ali na eni strani). Joe Sacco v svojem delu Footnotes in Gaza ${ }^{13}$ (2009) pogosto uporablja takšne (tudi zelo hitre) premike po časovni premici, ki služijo poudarjanju vsebine - nenehnega in neprekinjenega nasilja med Izraelci in Palestinci. ${ }^{14}$ Saccove podobe včasih, zavoljo dramatičnosti, poudarjanja nasilja in nenadnih napadov (sploh v njegovih vojnih grafičnih pripovedih Palestine ${ }^{15}$ in Footnotes), tudi prebijajo okvirje in udarjajo v »luknjo«, v praznino, in obenem kažejo tako na brezčasnost kot na prežečo nevarnost. ${ }^{16}$ Sacco uporablja tudi prekrivajoče se okvirje; $s$ tem načinom po navadi prikaže simultanost dogajanja, pa tudi časovno in prostorsko kaotičnost prikazane situacije.

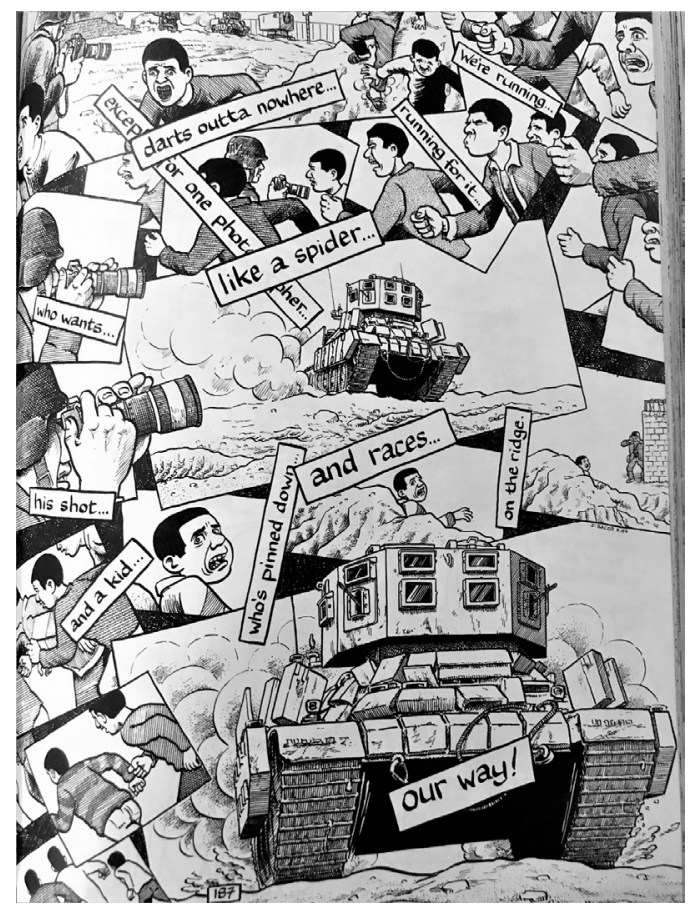

Slika 2: Sacco, Footnotes in Gaza 187

Pri analizi časovnega aspekta GP je treba omeniti tudi govorne (ali miselne) balončke. Besede $\mathrm{v}$ balončkih so po navadi $\mathrm{v}$ sedanjem času in imajo podobno funkcijo kot dialog ali monolog $\mathrm{v}$ zgolj verbalnih pripovedih.

${ }^{13}$ Delo ni prevedeno v slovenski jezik. Naslov bi se lahko glasil Opombe iz Gaze.

${ }^{14}$ Glej tudi Flis 136.

${ }^{15}$ Delo ni prevedeno v slovenski jezik.

${ }^{16}$ Glej Ann Miller 400-401. 
Kot pravi David Carrier v The Aethetics of Comics: „Govorni balonček je pomemben element stripa, saj ustvari entiteto beseda/podoba, ki se razlikuje od podob, ki ilustrirajo besedilo." (4) Razvrstitev govornih in miselnih balončkov (položaj balončka glede na druge balončke, položaj balončka v razmerju do prikazanega dejanja in do govorca) vsekakor vpliva na temporalni aspekt GP. Tudi balončke moramo brati v enakem zaporedju kot beremo podobe in/ali spremljevalno besedilo, torej znotraj bralne konvencije zahodnega sveta od leve proti desni in od zgoraj navzdol. Govorni balonček je nekaj, kar v realnem svetu ne obstaja, a vseeno bralci vseh starosti in s praktično kakršnimkoli kulturnim ozadjem vedo, kakšen je njegov namen. Avtorji Charles Forceville, Tony Veale in Kurt Feyaerts v članku z naslovom »Balloonics« v knjigi The Rise and Reason of Comics tolmačenje balončkov razlagajo s konvencijo, ki je del kode grafičnih pripovedi, kot pravijo. Balončki ne posredujejo informacij le $\mathrm{v}$ podobi teksta, saj so poleg tega važne tudi njihova oblika, barva, položaj na strani, velikost in postavitev repkov, ki izhajajo iz balončkov. Govorni balonček omenjeni avorji razumejo kot konceptualno metaforo. Konceptualne metafore so vzorci razmišljanja, ki naj bi predstavljali osnovo ali podlago za vsakodnevne metaforične izraze. Ti metaforični izrazi so po navadi jezikovni, lahko pa se pojavljajo tudi v podobah. Prepričani so, da tudi ko gre za balonček, ki je specifika stripovskega sveta, zaradi navezovanja ali povezovanja $\mathrm{z}$ osnovnimi kognitivnimi procesi tolmačenje ne zahteva posebnega ali posebej pridobljenega znanja. ${ }^{17}$ Potem je pogosto navzoče še spremljevalno besedilo, torej besede, ki jih ne povezujemo nujno z določenim likom; to besedilo je lahko v kateremkoli času. Primere spremljevalnega besedila najdemo tako pri Spiegelmanu kot pri Saccu in v manjši meri tudi pri Satrapi. Avtor se tu postavi v vlogo razlagalca, povezovalca dogodkov, komentatorja ali distanciranega opazovalca. Spodnji ilustraciji prikazujeta primera iz Spiegelmanovega Mausa (1980) in iz Saccovega dela Footnotes in Gaza (2009).

\footnotetext{
${ }^{17}$ Glej tudi glej Kukkonen, Contemporary 56-73.
} 
CLBERBERGI SO IMELI TOVARNO DVIGAL - ENO AAJVECJIH NA POLJSEEM ... TODA, KO SEM PRISEL \&A OBISK, SO ME SPREJELI KOT KRALJA ...
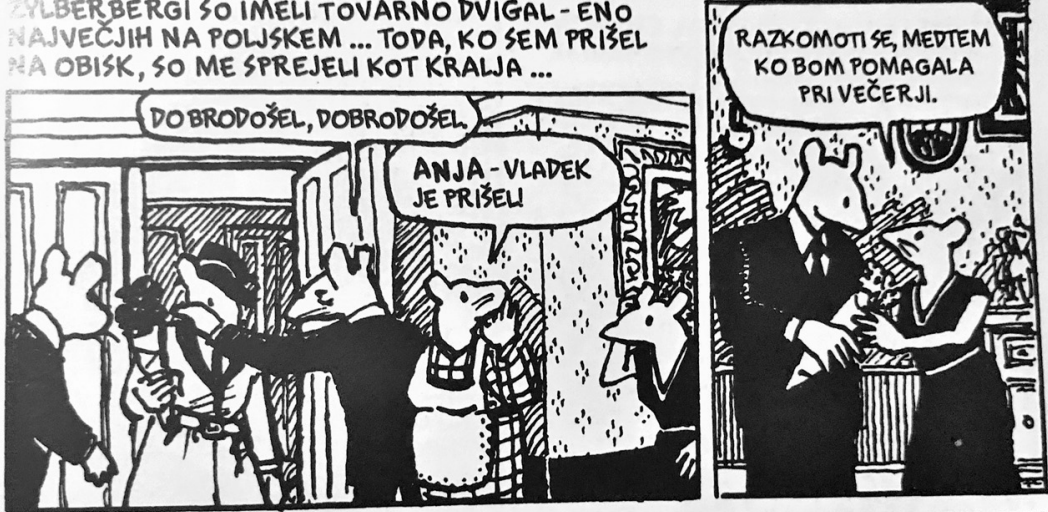

DABIUGOTOVIL, KAKŚNA GOSPODINJA JE, SEM POKUKAL V NJENO OMARO.
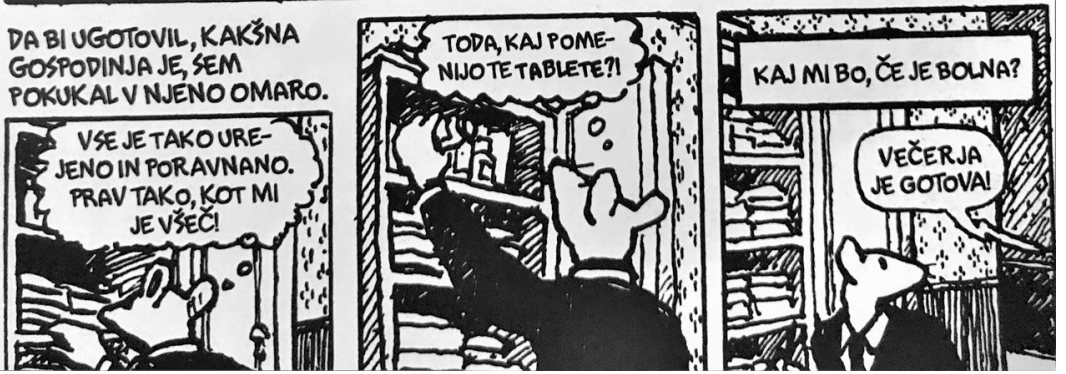

Slika 3: Spiegelman, Maus 21

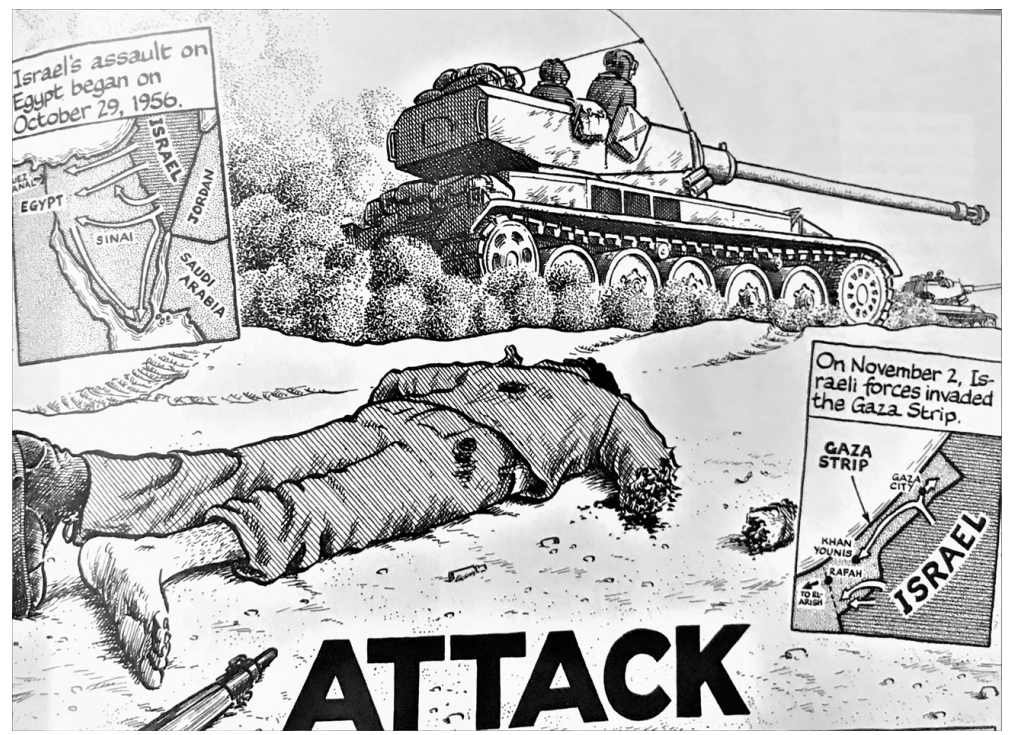

Slika 4: Sacco, Footnotes in Gaza 81 
Če se ozrem k Genettu, je to torej lahko glas ekstradiegetskega pripovedovalca ali pa raje (sledeč postgenettovski terminologiji) zunanjega fokalizatorja, ki je lahko tudi avtor sam. ${ }^{18}$ Kar zadeva pripovedovalce in fokalizatorje v kontekstu GP, se opiram tudi na stališče Alojzije Zupan Sosič, ki zagovarja mešanost ali sinkretičnost vrst in kategorij pripovedovalca ter pretočnost pripovedovalcev in fokalizatorjev (opre se tudi na teorijo Manfreda Jahna). ${ }^{19}$ Lahko seveda izpostavim, da so za analizo GP koristni tudi koncepti pripovedi in fokalizacije, kot jih zasnujeta Gerard Genette in Mieke Bal, vseeno pa se kot še primernejši kaže Jahnov model, ki razširi pojem fokalizacije s pomočjo kognitivnih pristopov. Manfred Jahn, kot povzema Alojzija Zupan Sosič v članku "Pripovedovalec in fokalizacija», je fokalizacijo razumel kot okno v pripovedni svet, ki omogoča bralcem videti dogodke skozi perceptualni zaslon s pomočjo fokalizatorja, delujočega kot zunajzgodbeni ali znotrajzgodbeni medij. $\mathrm{Na}$ ta način je razložena kot prvenstveno sprožilo za avtorje, pripovedovalce in bralce ter temeljni proces pripovedovanja in razumevanja zgodb, kar je nasprotno od tradicionalnega pojmovanja fokalizacije, ko je bila ta razlagana kot nekaj drugotnega v smislu filtra predstavitve že obstoječih pripovednih dejstev (Zupan Sosič, "Pripovedovalec« 65-66). V multimodalnih pripovedih (kot so GP), je fokalizacija stvar interpretacije, torej neprestane interakcije med tekstom in recepcijo (bralcem-gledalcem). Fokalizacija oziroma bralčevo razumevanje fokalizacije se razvija skozi proces branja.

\section{Vprašanje fokalizacije}

Kukkonen (v Contemporary Comics Storytelling) večkrat omeni, da je naratologija stripa v bolj ali manj začetni fazi in potrebuje sistematično obdelavo, največ pozornosti pa je po njegovem mnenju treba nameniti prav fokalizaciji, pripovedovalcu ter razliki med zgodbo in diskurzom. Temu pritrjujeta tudi Silke Horstkotte and Nancy Pedri v članku "Focalization in Graphic Narrative«, na katerega se bom pri analizi fokalizacije deloma oprla. ${ }^{20}$ Avtorici izhajata iz raziskav kognitivne naratologije, še posebej izpostavita Manreda Jahna, Davida Hermana in

${ }^{18}$ Glej Alojzija Zupan Sosič, »Pripovedovalec« 47-72 in delo Alenke Koron Sodobne teorije pripovedi.

${ }^{19}$ Manfred Jahn, „Focalization« in tudi »Windows of Focalization«.

${ }^{20} \mathrm{~V}$ zadnjih letih ni nastalo ravno veliko novih zapisov o fokalizaciji v grafičnih pripovedih, zato se opiram na tiste, ki izbrano problematiko najbolj jasno opišejo. 
Alana Palmerja. ${ }^{21} \mathrm{~V}$ članku govorita o tem, da se GP pri posredovanju pomena zanašajo na uravnotežen preplet semiotičnih kodov ali modalitet, obenem pa se vedno znova zastavlja vprašanje, kaj natančno predstavlja fokalizacijo v GP oziroma kako se ta demonstrira. Kot multimodalne pripovedi grafične pripovedi povezujejo različne semiotične modalitete, slike, besede in sekvenčnost ter nedvomno ponujajo bogat prostor za raziskovanje. Fokalizacija v multimodalnih medijih je večkrat nekaj ambivalentnega in zmuzljivega. Na primerih dela Marjane Satrapi Persepolis (2000) in Spigelmanovega Mausa bom pokazala nekaj možnosti za razumevanje in razlago fokalizacije v GP.

V GP tako pripoved kot fokalizacija lahko simultano delujeta na dveh modalnih pasovih, to pa lahko povzroča "vrzeli, premore in napetosti, ki jih v monomodalnih, zgolj verbalnih pripovedih ne najdemo" (Horstkotte in Pedri 336). Horstkotte in Pedri poudarjata, da je pri vpogledu v vidike fokalizacije v GP nujno treba upoštevati sledeče razlike med GP in fotografijo ter premičnimi slikami (filmom ali animacijo) na eni strani in verbalnimi pripovedmi na drugi:

- poleg multimodalnosti gre $\mathrm{v}$ GP za drugače kodirana čas in prostor; Thierry Groensteen ${ }^{22}$ temu reče "spacio-topia« (prostorotopija) ${ }^{23}$ semiotičnega sistema GP;

- oblikovanje tega "časa v prostoru" skozi okvirje in vmesne prostore (gutter), ki so ključni za pripoved;

- "prepletanje«GP - vsak okvir je vsaj v potencialnem, če ne dejanskem odnosu z drugimi okvirji, to pa ustvarja zgoščenost detajlov in definira tudi ritem pripovedi. ${ }^{24}$

Delo Marjane Satrapi Persepolis je narisano v črno-belem, minimalističnem slogu. ${ }^{25}$ Satrapi bralcu ponudi subtilno izpisano in izrisano zgodbo o odraščanju v Iranu v času islamske revolucije in v času iransko-iraške vojne. Slogovno Satrapi perzijsko ikonografijo prepleta z zahodnjaškim podobjem in simboliko, njene minimalistične podobe so stilizirane in ravno zaradi svoje simplifikacije še poudarjajo izraženo oziroma prikazano. Avtorica ne uporablja senčenja, temveč gre ves čas za monokromatske, črno-bele ilustracije.

${ }^{21}$ Glej predvsem David Herman, "Beyond « 119-142. Pomembna zapisa sta tudi njegova »Introduction« 1-30 in »Toward « 47-75. Glej tudi delo Alana Palmerja Fictional Minds.

${ }^{22}$ Glej Thierry Groensteen, The System of Comics.

23 "Topia« izvira iz grškega izraza »topos«, ki pomeni prostor, kraj.

${ }^{24}$ Glej Horstkotte in Pedri, "Focalization in Graphic Narrative« 336-337.

${ }^{25}$ Satrapijino delo natančno opiše Rocio G. Davis v članku »A Graphic Self» (264-279). 

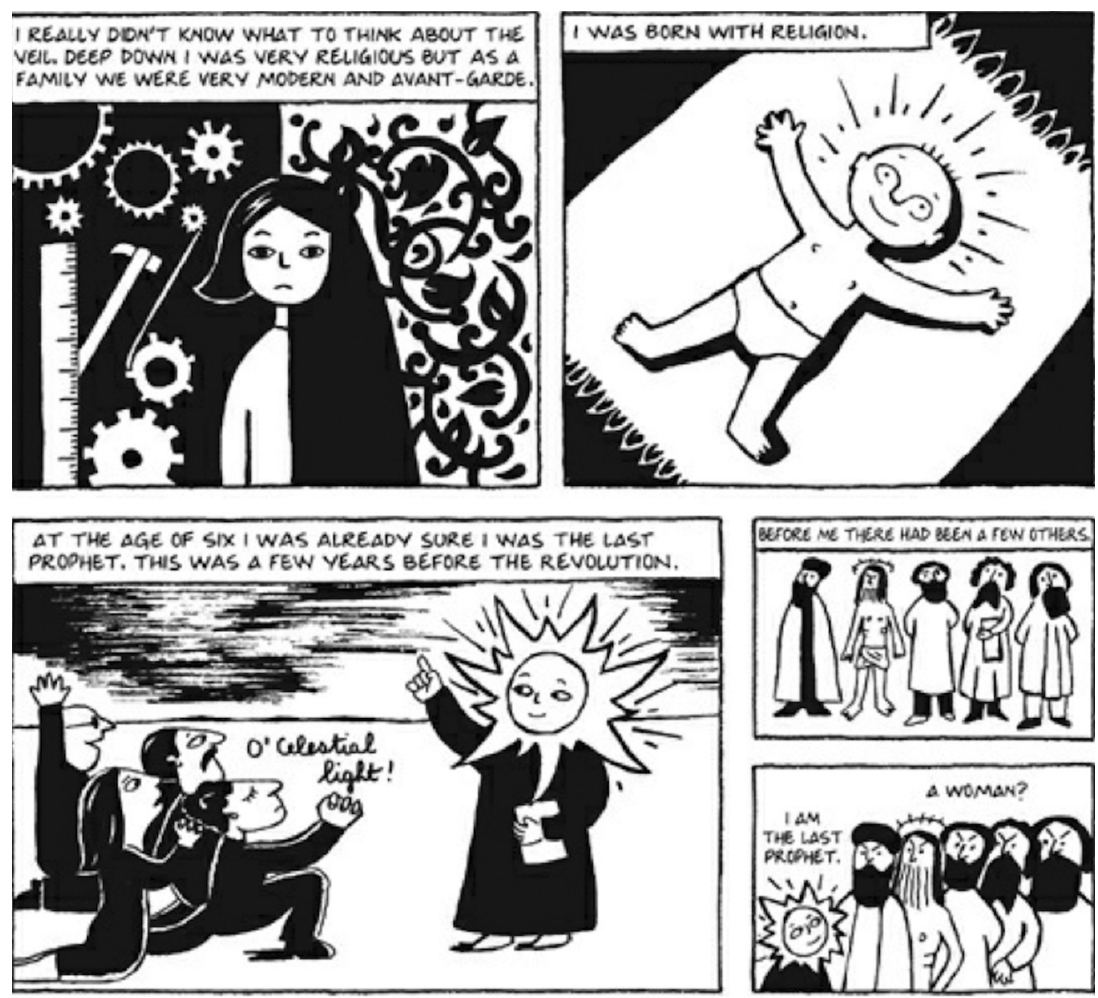

Slika 5: Satrapi, Persepolis 6

Strinjam se s Horstkotte in Pedri, ki menita, da je preprostost podob v delu Persepolis zgolj navidezna, veliko okvirjev namreč vsebuje intertekstualne aluzije in prikaze izkušenj, ki presegajo izkustveni in kognitivni svet deklice (male Marji), ki mu sledimo v prvem od obeh zvezkov. Skozi celotno delo se verbalno in vizualno soočamo z dvomi, težavami razumevanja in miselnimi vrtinci protagonistov. $\mathrm{Ni}$ vedno nemudoma razvidno, ali dojemanje in interpretacija dogodkov pripadata pripovedujočemu jazu ali pa gre za fokalizacijo, ki je del pripovednega sveta in pripada izbranemu protagonistu ali protagonistki. Persepolis je hibridno delo tudi v žanrskem vidiku: lahko bi ga opisali kot mešanico avtobiografije, zapisa (in orisa) izseka iz zgodovine Bližnjega vzhoda, knjiga ima tudi prvine, ki bi si jih lahko lastile ženske študije, feministična besedila, spominska proza in še kakšen žanr.

Satrapi raje uporablja vizualne metafore in simbolizem, $s$ katerimi nakazuje stališče, ki ga ne moremo vedno pripisati določenemu liku, kot da bi okvirje oblikovala v smislu jasne perspektive in fokalizacije. 
Kot primer navajam sekvenco, v kateri se družina Satrapi pogovarja o razmerah v Iranu po tem, ko državo zapusti šah. Satrapi vstavi okvir, $\mathrm{v}$ katerem družino obkroža stiliziran simbol hudiča $\mathrm{v}$ podobi kače. Ta podoba je $\mathrm{v}$ popolnem nasprotju z materinimi besedami v balončku, $\mathrm{v}$ katerem pravi, da je hudič (šah) odšel. Resnica je, da je šah še navzoč in da vdira v življenje družine. Čez nekaj tednov so v Iranu oblast resnično prevzeli fundamentalisti, nedavno izpuščeni politični zaporniki so bili vnovič zaprti, mučeni in ubiti, Iran pa se je kmalu zapletel v krvavo vojno v Sadamom Huseinom.
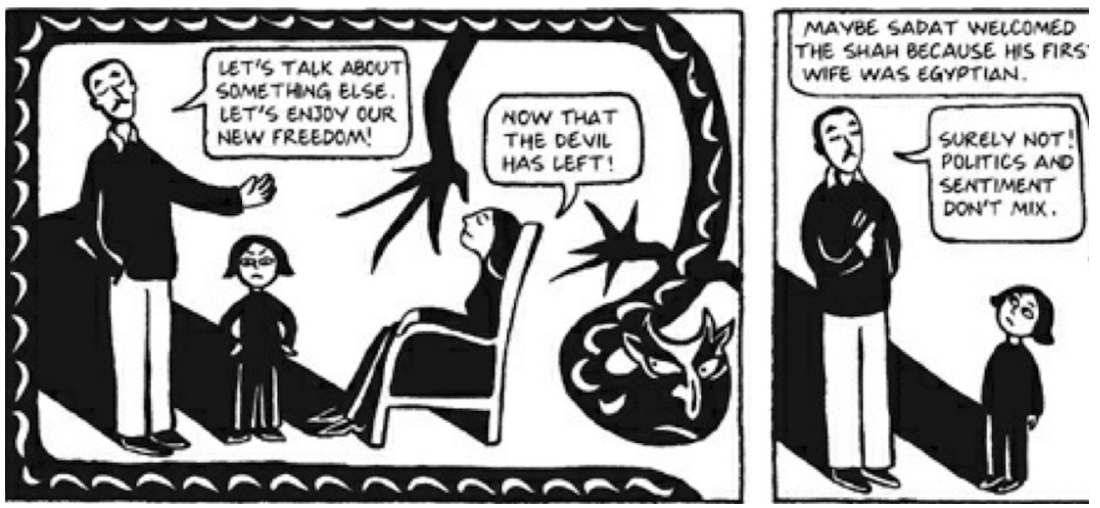

Slika 6: Satrapi, Persepolis 43

Kačo lahko vidimo kot vpogled $\mathrm{v}$ politično in zgodovinsko stanje in kot oceno situacije, kot simbol retrospektivnega zrenja na dogodke, v tem primeru okvir s kačo odraža videnje zrelejšega pripovednega "jaza" in ne neposredno doživljajoči otroški »jaz«. Lahko pa kačo beremo kot izraz Marjaninega (otroškega) prizadevanja, da bi razumela kompleksno situacijo in prevprašala interpretacije dogodkov, ki jih ponudijo njeni starši. Njen namrgoden izraz na obrazu kaže na dvome, ki se ji porajajo, ponujena razlaga se ji ne zdi dovolj prepričljiva. Vseeno pa se zdi verjetnejša možnost, da imamo opravka z distancirano, zrelo, retrospektivno pripovedovalko (odrasla Marjane), ki pozna podrobnosti političnega dogajanja in kačo vidi kot simbol za šaha. Bralec se mora tako odločiti, katera verzija fokalizacije se mu izrisuje kot verjetnejša v izbrani situaciji, in včasih naletimo na primere, ki so lahko dvoumni. V tem specifičnem primeru sta naša branje in razumevanje zares odvisna od tega, ali fokalizacijo pripišemo literarni osebi (mladi Marji) ali odrasli pripovedovalki. Če jo pripišemo literarni osebi, dobimo vpogled v njen miselni svet (ki je bogat, a zaradi njene mladosti vseeno omejen), če pa govorimo o fokalizaciji, ki je del odrasle pripovedovalke, dobimo drugačen uvid. 
$\mathrm{V}$ tem primeru časovni odnos med osnovnim okvirjem in "vloženo" (dodano) podobo kače ni popolnoma jasen in zato ni jasna fokalizacija. Kognitivni aspekt je torej ključen pri opredelitvi fokalizacije.

V Spiegelmanovem Mausu, ki je kompleksna mešanica biografije in avtobiografije, imamo opraviti z dvema časovnima premicama in dvema pripovedovalcema, torej je tu model multimodalne naracije in fokalizacije bolj niansiran in lažje opredeljiv. Svet druge svetovne vojne stoji ob boku New Yorku v 80. letih prejšnjega stoletja in intradiegetska pripoved (zgodba Vladkovega preživetja) se prepleta z njegovimi ekstradiegetskimi pogovori (intevjuji) s sinom (Artom Spiegelmanom), ki piše/riše zgodbo svoje družine. Vladek je torej intradiegetski pripovedovalec (Poljska, 40. leta prejšnjega stoletja), Art pa je ekstradiegetski pripovedovalec ( $\mathrm{v} 80$. letih) kot tudi risar (vizualni narator) tako ekstradiegetske kot intradiegetske pripovedi. Občasno pa se pravzaprav tudi sam (ko dvomi o uspehu svojega pisanja in risanja izbrane zgodbe) postavi v vlogo intradiegetskega pripovedovalca (razmišljevalca). Poleg tega je Artova pripoved očetove zgodbe personificirana, še posebej močno z uporabo živalskih metafor (Judi kot miši, Poljaki kot prašiči, Nemci kot mačke, Američani kot psi).

Ker imamo tako pri Satrapi kot pri Spiegelmanu opravka z mešanjem biografskega in avtobiografskega (grafičnega) zapisa, je določitev fokalizacije še težja kot $\mathrm{v}$ primerih, kjer pripovedovalec ni del pripovednega dogajanja (ter zgolj »od zunaj« komentira, torej ni izkušajoči "jaz") in tam, kjer imamo opravka z različnimi časovnimi premicami. V Mausu recimo lahko najprej vidimo Vladkovo intradiegetsko pripoved, v naslednjem okvirju pa se živalska metafora zamenja in izpostavi se vprašanje fokalizatorja. Zdi se, da je nenazadnje Art tisti, ki v 80. letih dvomi oziroma niha med dvema različnima vizualnima reprezentacijama zgodbe. Vladek pravi, da je identiteta zapornikov tako ali tako nepomembna. Prav zaradi dvomov Spiegelman tudi zasenči drugi okvir. Horstkotte in Pedri govorita o pripovedni negotovosti (narrative uncertainty), značilni za Spiegelmanovo delo. ${ }^{26}$ Poglavitna razloga zanjo sta razplastena zgodba in kompleksna fokalizacija. ${ }^{27}$

V Mausu se preskok v fokalizaciji zgodi, ko se zunanja, ekstradiegetska pozicija (zapornik je narisan kot miš) spremeni v Artovo (ki je tudi lik v zgodbi) notranjo fokalizacijo, ki podobo spremeni v mačko. Čeprav je fokalizator v obeh okvirjih Artie, gre v prvem okvirju za zuna-

${ }^{26}$ Podoben dvom ali nestabilnost vedenja, resnice in še posebej spomina zasledimo tudi v delih Joeja Sacca. Hillary Chute govori o "samozavedajoči metodologiji« Saccovega dela. Glej Chute, Disaster 228.

${ }^{27}$ Glej Horstkotte in Pedri 330-331. 
njega fokalizatorja, ki prikazuje Vladkove spomine iz časa vojne, v drugem okvirju pa postane Artie notranji fokalizator (lik), ki v New Yorku v 80. letih 20. stoletja domneva, da bi bil zapornik lahko tudi Nemec. Čeprav je torej sama zgodba iz 40. let Vladkova (občasno notranji fokalizator, večinoma pa je tudi on zunanji, saj pripoveduje v 80. letih), je Artov prikaz te zgodbe - torej vizualna interpretacija - tista, ki se zdi v večini okvirjev ključna fokalizacija (Vladkova pripoved v 80. letih 20. stoletja je podana skozi Artovo vizualno oblikovanje ali interpretacijo). Opraviti imamo torej z dvema zunanjima fokalizatorjema - eden deluje na vizualnem nivoju, drugi na verbalnem. Tudi Art se premika med zunanjim in notranjim pripovedovalcem. ${ }^{28}$ Takšna gibanja ali nihanja (med obema pripovedovalcema) so prevladujoča pripovedovalska in fokalizacijska pozicija v Spiegelmanovem grafičnem romanu. Maus ima torej dve zgodbi, ki ju pripovedujeta dva pripovedovalca, postavljeni pa sta na na dve semiotični liniji, imamo dva notranja fokalizatorja in dva zunanja fokalizatorja.

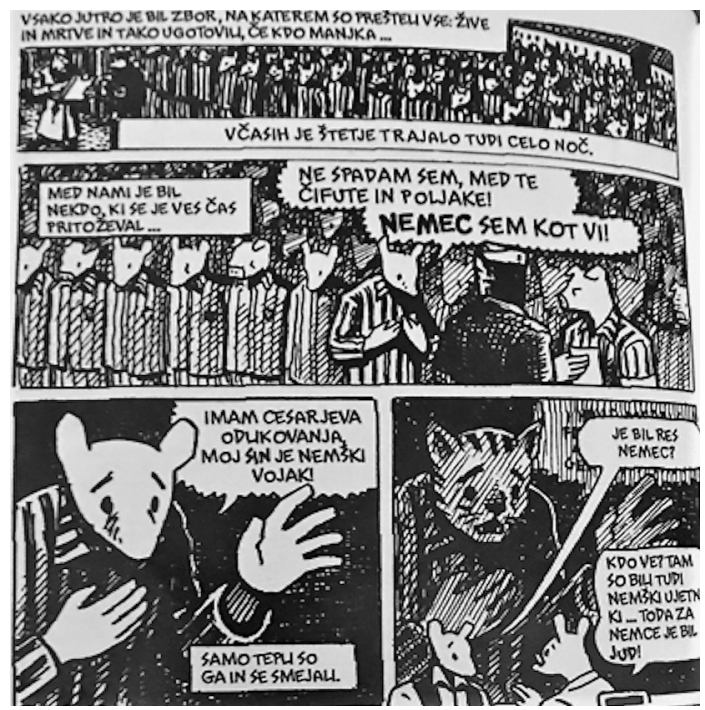

Slika 7: Spiegelman, Maus 210

Tudi Joe Sacco v svojih delih spreminja fokalizatorje. Ustrezno se zdi govoriti o pretočnosti fokalizatorjev, saj se, recimo v delih Palestine in

${ }^{28}$ Erin McGlothlin v članku "Art Spiegelman's Practice» govori o metareferenčnem značaju Mausa; s tem terminom označi obče avtorefleksivne značilnosti Spiegelmanovega dela. 
Footnotes in Gaza selimo od videnja in dojemanja Palestincev (ki je prevladujoče) do perspektive izraelskih vojakov in tudi Saccovega lastnega vpogleda (ki pa je predvsem v Footnotes in Gaza omejen na minimum). Kot je mogoče razbrati iz omenjenih del, so razplastenost in fragmentiranost zgodbe ter $\mathrm{z}$ njima povezano vprašanje fluidne fokalizacije lastnosti, ki so zlasti izrazite v GP, ki upovedujejo travmatične dogodke in oživljajo spomine nanje. Ambivalentnost fokalizacije in fragmentarna struktura pripovedi pripomoreta tudi k prikazu soobstoja različnih, spreminjajočih se, subjektivnih resnic, ki jih posredujejo različni pripovedovalci (lahko tudi skozi različne, prepletajoče se časovnice). ${ }^{29}$ Kot pravi McCloud v delu Kako nastane strip: "Strip je fragmentaren medij, tu je par besed, tam košček slike, če je dobro narejen, pa lahko bralci te fragmente med branjem povezujejo in doživljajo zgodbo kot povezano celoto." (129) Bralec delce sestavlja v celoto in več ko ima na razpolago perspektiv, celovitejša je njegova slika dogajalne situacije.

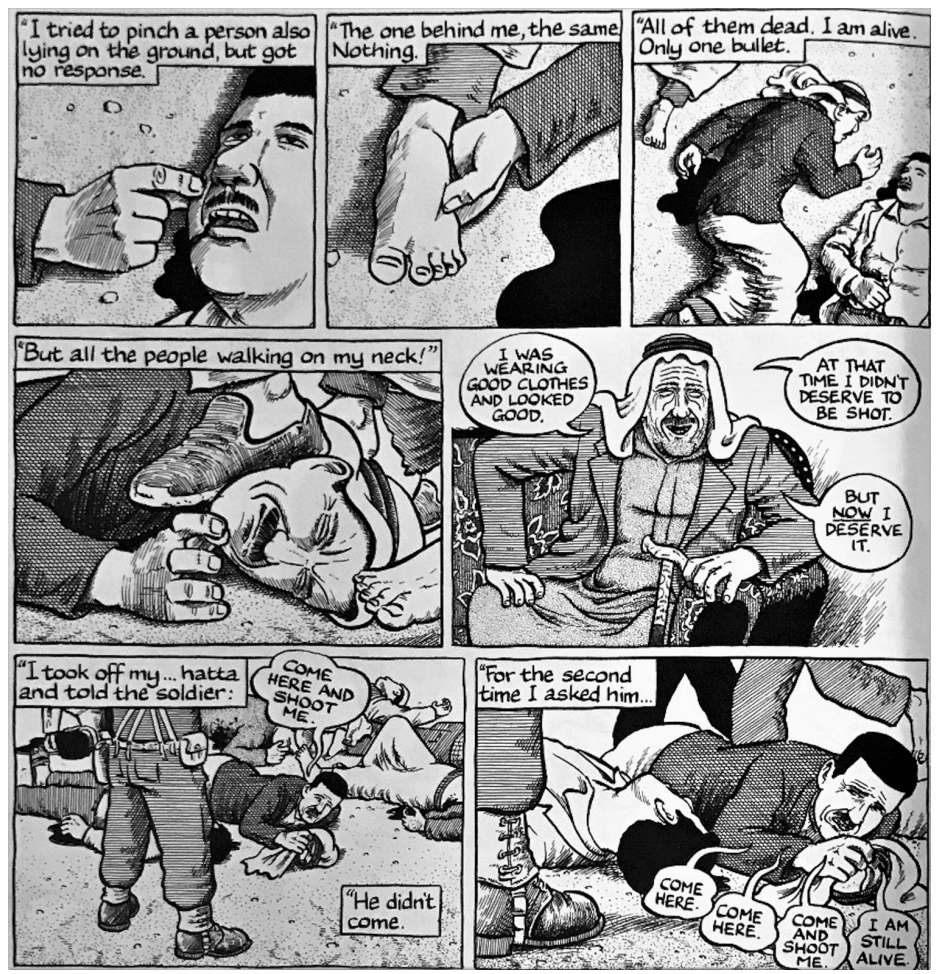

Slika 8: Sacco, Footnotes in Gaza 222

\footnotetext{
${ }^{29}$ Glej tudi Flis, »Joe Sacco in literarno novinarstvo v podobi stripa« 142-143.
} 


\section{Sklep}

V zaključku lahko pritrdim Scottu McCloudu, ki pravi, da vsi dojemamo svet skozi svoje čute in čuti lahko vedno znova opozarjajo na svet, ki je fragmentiran in nepopoln. Naše dojemanje "realnosti« temelji na veri ali na prepričanju, ki je subjektivno in zgrajeno iz fragmentov. Še tako razgledan in načitan človek vidi le fragmente (velikokrat ne povsem doumljive) celote, karkoli že ta celota je. McCloud imenuje opazovanje delcev, fragmentov in njihovo kognitivno povezovanje $\mathrm{v}$ zamišljene (trenutne) celote dopolnjevanje ${ }^{30}$ (Kako razumeti 64-65). Tako $\mathrm{v}$ življenju kot tudi med branjem stripov smo torej ves čas v iskanju vsaj začasnih zaključkov. Narativni principi GP, še posebej sekvenčna narava in fragmentiranost, se torej dobro ujamejo $s$ človeškim dojemanjem realnosti in s procesom spominjanja. Poleg tega so GP pluralen medij, saj povezujejo različne perspektive in tako bralcu ponudijo različne (včasih čisto nasprotujoče si) poglede, ta princip pa znova dobro posnema ali uteleša življenjsko stvarnost. Če umetnik (tudi stripar) želi, da ga bo bralec/gledalec razumel, mora upoštevati tisto, kar je skupno naši izkušnji »biti človek«. Pri tem je avtor GP žanrsko neomejen, obravnava lahko katerokoli temo ali aspekt življenja, s tem pa GP lahko postane odlično umetniško upovedana realnost življenja. Bralec in avtor sta v GP zapletena v ples vidnega in nevidnega - skupaj ves čas ustvarjata nekaj novega in tako fragmentiranim stvarnostim podarjata (začasne) izteke ali zaključke.

\section{LITERATURA}

Baetens, Jan. "Stories and Storytelling in the Era of Graphic Narrative«. Stories. Ur. Ian Christie in Annie van den Oever. Amsterdam: Amsterdam University Press, 2018. $27-45$.

Baetens, Jan, Hugo Frey in Stephen E. Tabachnick. "Introduction«. The Cambridge History of the Graphic Novel. Cambridge: Cambridge University Press, 2018. 1-18.

Barthes, Roland. "An Introduction to the Structural Analysis of Narrative«. Trans. Lionel Duisit. New Literary History 6.2 (1975): 237-272.

Carrier, David. The Aesthetics of Comics. University Park: Pennsylvania State University Press, 2000.

Chute, Hillary. Graphic Women: Life Narrative \& Contemporary Comics. New York: Columbia University Press, 2010.

Chute, Hillary. Disaster Drawn: Visual Witness, Comics and Documentary Form. Cambridge MA in London: Harvard University Press, 2016.

${ }^{30}$ Tako prevaja "closure« prevajalec McCloudovega dela Kako razumeti strip Izar Lunaček. Avtorica članka predlagam tudi drugo možnost prevoda: zaključevanje. 
Davis, Rocio G. »A Graphic Self: Comics as autobiography in Marjane Satrapi's Persepolis«. Prose Studies 27.3 (2005): 264-279.

Eisner, Will. Comics and Sequential Art. New York: W.W. Norton \& Company, 1985.

Eisner, Will. Graphic Storytelling and Visual Narrative. Florida: Poorhouse Press, 1996.

Flis, Leonora. "Joe Sacco in literarno novinarstvo v podobi stripa: žanrski preplet literature, stripa, novinarstva in zgodovine«. Primerjalna književnost 37.2 (2014): $129-150$.

Forceville, Charles, Tony Veale in Kurt Feyaerts. „Balloonics: The Visuals of Balloons in Comics". The Rise and Reason of Comics and Graphic Literature: Critical Essays on the Form. Ur. Joyce Goggin in Dan Hassler-Forest. London: McFarland \& Company, Inc. Publishers, 2010. 56-73.

Goggin, Joyce, in Dan Hassler-Forest. "Introduction«. The Rise and Reason of Comics and Graphic Literature: Critical Essays on the Form. Ur. Joyce Goggin in Dan Hassler-Forest. London: McFarland \& Company, Inc. Publishers, 2010. 1-4.

Groensteen, Thierry. The System of Comics. Prev. Bart Beaty in Nick Nguyen. Jackson, Mississippi: University Press of Mississippi, 2007.

Hančič, Miha. Avtorski strip. Diplomsko delo. Mentor Bojan Kovačič. Somentorica: Tonka Tacol. Univerza v Ljubljani, Pedagoška fakulteta. Tudi na spletu. Dostopano 18. 1.2020.

Herman, David. „Introduction«. Narratologies: New Perspectives on Narrative Analysis. Ur. David Herman. Columbus: The Ohio State University Press, 1999. 1-30.

Herman, David. »Toward a Transmedial Narratology«. Narrative Across Media: The Languages of Storytelling. Ur. Marie-Laure Ryan. Lincoln in London: University of Nebraska Press, 2004. 47-75.

Herman, David. "Beyond Voice and Vision: Cognitive Grammar and Focalization Theory«. Point of View, Perspective, Focalization: Modeling Mediacy. Ur. Peter Hühn, Wolf Schmid, Jörg Schönert. Berlin in New York: Walter de Gruyter, 2009. 119-142.

Horstkotte, Silke, in Nancy Pedri. "Focalization in Graphic Narrative«. Narrative 19.3 (2011): 330-357.

Iser, Wolfgang. Bralno dejanje: teorija estetskega učinka (prev. A. Leskovec). Ljubljana: Studia humanitatis, 2001.

Jahn, Manfred. "Windows of Focalization: Deconstructing and Reconstructing a Narratological Concept«. Style 30.2 (1996): 241-267.

Jahn, Manfred. "Focalization«. The Cambridge Companion to Narrative. Ur. David Herman. New York: Cambridge University Press, 2008. 94-109.

Koron, Alenka. Sodobne teorije pripovedi. Ljubljana: Založba ZRC SAZU, 2014.

Kukkonen, Karin. "Comics as a Test Case for Transmedial Narratology«. SubStance 40.1 (2011) (Issue 124: Graphic Narratives and Narrative Theory): 34-52.

Kukkonen, Karin. Contemporary Comics Storytelling. Lincoln and London: University of Nebraska Press, 2013.

Lefèvre, Pascal. "Narration in Comics". Image and Narrative: Online Magazine of the Visual Narrative August 2000. Splet. Dostopano: 30. 11. 2019.

Marčetić, Adrijana. "Postklasična naratologija: koliko je prirodna prirodna naratologija?«. Od narativa do narativnosti: pola veka naratologije: tematski zbornik radova. Ur. Snežana Milosavljević-Milić, Jelena Jovanović in Mirjana Bojanić-Ćirković. Niš: Filozofski fakultet, 2018. 73-85.

McCloud Scott. Kako nastane strip: pripovedne skrivnosti stripa, mange in risanega romana. Prev. Maša Peče. Ljubljana: Društvo za oživljanje zgodbe 2 koluta, 2010. 
McCloud, Scott. Kako razumeti strip: o nevidni umetnosti. Prev. Izar Lunaček. Ljubljana: Cankarjeva založba, 2011.

McGlothlin, Erin. "Art Spiegelman's Practice from Maus to MetaMaus«. The Cambridge History of the Graphic Novel. Ur. Jan Baetens, Hugo Frey in Stephen E. Tabachnick. Cambridge in New York, 2018. 203-218.

Mikkonen, Kai. "Remediation and the Sense of Time in Graphic Narratives". The Rise and Reason of Comics and Graphic Literature: Critical Essays on the Form. Ur. Joyce Goggin in Dan Hassler-Forest. London: McFarland \& Company, Inc. Publishers, 2010. 74-86.

Miller, Ann. "Joe Sacco, Graphic Novelist as Political Journalist". The Cambridge History of the Graphic Novel. Ur. Jan Baetens et al. Cambridge: Cambridge University Press, 2018. 389-404.

Sacco, Joe. Palestine: A Nation Occupied. Seattle, WA: Fantagraphics Books, 1996.

Sacco, Joe. Footnotes in Gaza. New York: Metropolitan Books, 2009.

Satrapi, Marjane. Persepolis. London: Vintage Books, 2008.

Spiegelman, Art. Maus. Prev. Oto Luthar. Ljubljana: Založba ZRC, 2010.

Štandeker, Špela. "Slogovna in vsebinska raznolikost stripovskega izraza«. Tomaž Lavrič: Stripi/Comics. Ljubljana: Moderna galerija, 2010. 5-10.

Zupan Sosič, Alojzija. »Postklasična teorija pripovedi«. Slavistična revija 61.3 (2013): 495-506.

Zupan Sosič, Alojzija. »Pripovedovalec in fokalizacija». Primerjalna književnost 37.3 (2014): 47-72.

Zupan Sosič, Alojzija. Teorija pripovedi. Maribor: Litera, 2017.

\section{Graphic Narratives and Narrativity}

Keywords: postclassical narratology / hybrid genres / graphic novel / graphic narrative / narrativity / Spiegelman, Art / Satrapi, Marjane / Sacco, Joe

The article focuses on the narrative principles of graphic narratives representing a hybrid genre that dwells at the intersection of literary and visual storytelling. The genre's multimodality is also viewed through the prism of certain principles of postclassical narratology. Graphic narratives occupy the intersection of showing and telling stories; they always tell a story, so they are a narrative genre. Graphic storytelling enables us to pose some fundamental questions that concern, for example, the temporal aspect of narrativity (understood as a collection of formal and contextual traits that define a narrative) and the issue of focalization. Graphic narratives treat time somewhat differently from (merely) verbal narratives, as a sense of time is created through the relationship between the visual and the verbal. Moreover, apart from the (mostly) framed images, graphic narratives also contain the so called "gutter" or an empty space 
between the frames. Scott McCloud, himself a comics theorist and comics artist, says that gutter is the place where the illusion of the movement of space and time takes place. Using the examples from a few graphic narratives (by Art Spiegelman, Joe Sacco, and Marjane Satrapi), the article shows the specifics of graphic storytelling, which, with its sequential nature, the principles of montage, the composition of individual pages, and other structural characteristics, enables the formation of narratives. When we talk about graphic narratives, it is appropriate to talk about the transgeneric and transmedial narratology, hence the article also exposes the role of postclassical narratology in the process of interpreting and understanding graphic narratives.

1.01 Izvirni znanstveni članek / Original scientific article

UDK 82.0-31:741.52

DOI: https://doi.org/10.3986/pkn.v43.i1.03 